\title{
Poly(lactic acid) and its composites as functional materials for 3-D scaffolds in biomedical applications: A mini-review of recent trends
}

\author{
S. T. Sikhosana ${ }^{1}$, T. P. Gumede ${ }^{1 *}$, N. J. Malebo ${ }^{1}$, A. O. Ogundeji ${ }^{1,2}$ \\ ${ }^{1}$ Department of Life Sciences, Central University of Technology, Free State, Bloemfontein, South Africa \\ ${ }^{2}$ Department of Microbial Biochemical and Food Biotechnology, University of Free State, 205 Nelson Mandela Drive, \\ Park West Bloemfontein, Free State, South Africa
}

Received 7 September 2020; accepted in revised form 9 December 2020

\begin{abstract}
Patients sometimes lose organs and/or organ functions due to disease and injury, which may result in permanent disabilities. Advanced biotechnological practices can now afford victims of these incidences an opportunity to repair some of the damaged tissues or organs without the need for a donor. This can be achieved by reconstruction of the damaged tissue or organ through scaffold and cell technologies. Scaffolds serve as template material for neo-organs to guide and accelerate cell growth. The structure of a scaffold material must meet certain design parameters to achieve optimal functionality in tissue engineering. Pre-requisites include surface compatibility and architectural suitability with the host environment. Polymeric scaffolds derived from polymer blends have the prospects to control the physical and chemical environment of the biological system. In this review, potential roles, general properties, advantages, and disadvantages of poly (lactic acid) and its composites as functional materials for scaffolding will be outlined. PLA and its composites have been subjects of research for some decades due to non-toxicity and the ability to mimic native tissue. Though PLA and composites have demonstrated great potential for various biomedical applications, a lot still needs to be done for them to compete with donor and prosthetic organs.
\end{abstract}

Keywords: polymer composites, PLA, scaffolds, tissue engineering, 3-D bioprinting

\section{Introduction}

Injury and illness are the main causes of human body tissue damage and degeneration, making it essential for relevant industries to facilitate their repair, replacement, and regeneration. Traditional and modern methods of treatment generally involve tissue or organ transplant, which may be of autografts or allografts. Autografting focuses on the transplantation of tissue from one part of the body to another in the same person, whereas allografting focuses on tissue transplant from one person to another [1-4]. Although to some extent these methodologies have been proven effective, they both have risks and limitations in their applications such as: (i) the need for organs always surpasses the number of donated organs; (ii) possible exposure to pathogens and cellular antigens of host tissue or organ which may lead to rejection of the implant; (iii) healthy tissues may be damaged during the tissue excision process; (iv) prosthetic implants lack full capacity and the ability to restore normal tissue functions [3, 5-8].

The World Health Organisation (WHO) describes organ transplantation as an established form of treatment that is nowadays acknowledged globally as the best and only effective therapy for the end-stage failure of vital organs such as livers, kidneys, heart, and

$\overline{{ }^{*} \text { Corresponding author, e-mail: tgumede@cut.ac.za }}$ 
lungs. Thus, organ transplantation strives to improve the quality of life. However, organ shortage has been identified as a pervasive worldwide public health challenge. Global Observatory on Donation and Transplantation, which is a branch of WHO that deals with the global statistics or organ donation and transplantation, estimates that currently only $10 \%$ of the global need for organ transplantation is met. As a result of the shortage, an increasing number of people die in waiting, while others resort to unlawful and unethical pathways of obtaining organs. Moreover, when patients finally receive that long-awaited organ, they become subjected to lifelong regimes of immunosuppressant drugs to prevent rejection, and that usually presents the risk of contracting life-threatening diseases such as cancer. While improvements in immunosuppression have immensely improved transplant success rates and graft survival, $50 \%$ of the organs transplanted fail within the first ten years of the procedure, along with other important organs [9-12]. The future of transplantation does not only depend on the ability to create implants when the need arises but also on the potential to selectively create immune tolerance of implants while preserving the ability of the patients to mount an immune reaction to infection [13-15]. Thus, tissue engineering and regenerative medicine approaches offer the promise of new and restored organs to overcome these challenges [8, 16-18].

Tissue engineering, which is often used synonymously with regenerative medicine, is a field of study that involves the development of growth and regenerative techniques for connective tissues or organs. It is a multifaceted discipline that brings together the fields of Life sciences and Engineering: clinical, mechanical engineering, polymer science, genetics, and others. Alternative to donor sourced or prosthetic replacements, its main objective is to reconstruct novel biological substitutes that can maintain, restore, and improve the original tissue functions using patients' cells. The risk of infection and organ rejection can be minimized significantly by collecting cells from patients and thus, limiting the need to utilize immunosuppressive drugs. To achieve its goal, tissue engineering relies on interactions within the 'tissue engineering triad', which is a combination of biomaterials, cells, growth factors, and regulatory signals, as illustrated in Figure 1. Biomaterials are seeded with tissue-derived cells and generally function as models to provide architectural support and shape for new

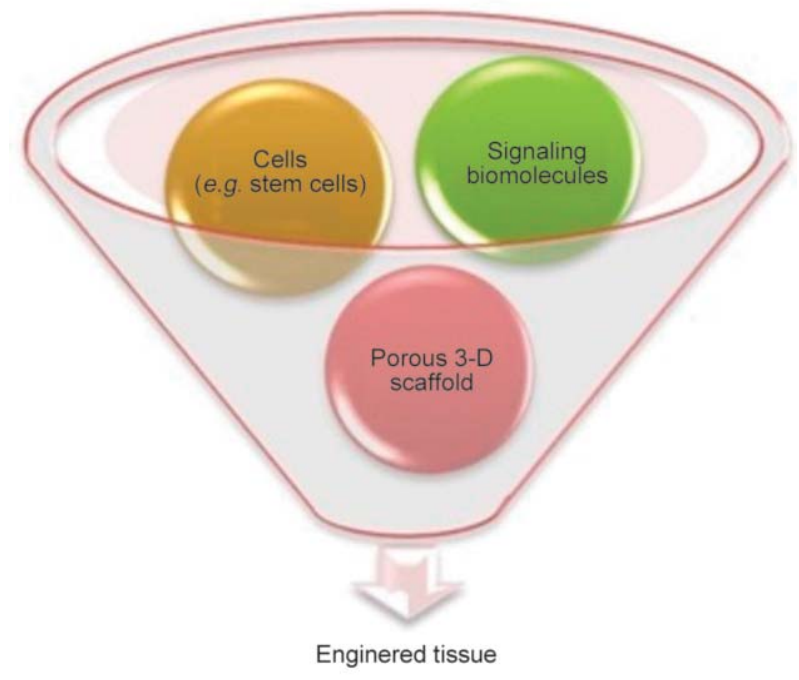

Figure 1. Tissue engineering triad.

tissue formation $[1,5,18-20]$. Skin is the first tissue to be successfully regenerated with the aid of a twodimension scaffold (2-D) and has been in use commercially for the past 25 years, which has led to many studies on three dimensional (3-D) structures for the development of other functional organs [21-24].

Although tissue engineering approaches comprise several important components, the presence of a biodegradable and biocompatible 3-D scaffold is crucial to provide niches and structural support to the cells. The artificial tissue and scaffold that would be transplanted into patients' bodies should possess the geometric shape of the damaged tissue or organ [2, 25-28]. Several 3-D porous scaffolds made from various kinds of biodegradable materials have been developed using different fabrication techniques. Poly(lactic acid) (PLA) and its copolymers have been widely employed for this purpose, not only for its exceptional in vivo compatibility and biodegradability but also due to the chirality of lactic acid (Land D-lactic acid) that can be leveraged to synthesize PLA with different stereo-regularities [29-33]. Irrespective of the widespread research on PLA as a biomaterial for applications in tissue engineering, many of the studies are a generalization of all FDA approved biopolymers and their potential roles. This review focuses exclusively on poly (lactic acid) and its composites: current and future roles in 3-D scaffolding. Its core properties, that is, biodegradability, biocompatibility, and thermoplasticity, are defined from a biological perspective to align material with proper application. Thus, the study is intended to address the following questions: what makes PLA and its composites good candidate materials for 3-D 
scaffolds in biomedical applications; where, in biomedical applications, are they suitable for use?

For this review, the following libraries were visited to search for articles, journals, book chapters, and theses posted from 1980 to date: Science Direct, Research Gate, Springer, Frontiers, PubMed, Google Scholar, IntechOpen, eXPRESS Polymer Letters including other internet sources such as WHO. The researcher used the following keywords as a research guide: tissue engineering, organ and/or a transplant, PLA and/or composites, 3-D scaffold, biodegradability, biocompatibility, thermoplasticity, and fabrication. The review is divided into different sections. The first section provides a more comprehensive overview of PLA as a biomaterial and its aspiration in the design and fabrication of 3-D scaffolds. The overview is followed by improvement of PLA through the composite formation with other materials to overcome its shortfalls and outline research milestones thus far. Lastly, the paper deliberates on various methodologies applied in constructing PLA scaffolds for tissue engineering applications, from simple solvent casting to more sophisticated technologies, including 3-D bioprinting. This information could be especially beneficial to up and coming researchers who are looking into smart materials and techniques that can be employed to design solid organs (hearts, livers, kidneys).

\section{PLA scaffolds}

The field of tissue engineering relies on scaffolds to act as templates for developing tissues. Before any tissue can be repaired or regenerated, scaffolds that are anatomically and functionally similar to the original tissue need to be designed and manufactured. Therefore, scaffolds should provide the appropriate mechanical properties and stability of the shape required to resist stresses and maintain the integrity of the designed structure $[2,4,34]$. According to Dhandayuthapani et al. [5], scaffolds are defined as three-dimensional porous solid biomaterials designed to perform the following functions: (i) act as an Extracellular matrix (ECM) which creates a suitable platform for cellular interactions, cell adhesion, and removal of toxic metabolites; (ii) permit mass transport of oxygen and nutrients for cell survival, proliferation and differentiation; (iii) biodegrade and resorb at a controllable rate of tissue regeneration under preferred culture conditions in vivo and/or in vitro; (iv) provide mechanical support and biocompatible properties to match those of the tissues at the site of implantation [5, 24, 35, 36].

Several biodegradable and biocompatible polymers of synthetic and natural origins such as poly(lactic acid) (PLA), poly ( $\varepsilon$-caprolactone) (PCL), Poly (dioxinone) (PDO) and poly (trimethylene carbonate) (PTMC), have been identified and are currently being developed into substantial materials for tissue engineering and regenerative medicine $[6,24,36,37]$. These polymers undergo hydrolytic biodegradation and can be excreted through normal body metabolic pathways. Most of these polymeric materials have been employed as sutures, while others are currently being synthesized as implant material alternatives due to their ability to eliminate the need to remove implants and offer long-term structural support. Amongst the frequently used biodegradable polymers for medical applications, poly (lactic acid) has become one of the most important polymers. This is after the United States Food and Drug Administration (FDA) approved it as biodegradable and biocompatible material for use in human bodies due to its absorbable and non-toxic nature [25, 26, 29, 36, 37]. PLA is derived from naturally occurring lactic acid, which is a product of the fermentation of sugars from organic sources. It is a chiral molecule that exists in three enantiomeric states, L-Lactide, D-Lactide, and meso-lactide. From the three enantiomeric states, the most widely used polylactides are the poly (L-Lactide) (PLLA) and poly (D-Lactide) (PDLA), respectively [31, 32, 38-40].

Due to the unique qualities of PLA, that is biodegradability, biocompatibility, thermoplasticity, and environmental friendliness, PLA is pertinent to medical applications. It has been used as a biomaterial for surgical implants, drug delivery systems, as well as three-dimensional porous scaffolds for neo-tissue growth $[6,31,36,37]$. In tissue engineering, the surface properties of materials play a critical role in determining their applications. The physiological properties of PLA, such as mechanical, thermal, and degradation, are influenced by the stereoregularity of this material. These traits are important in tissue engineering applications, as scaffolds can be successfully engineered to match the mechanical properties of the native tissue. Hence the different surface modification strategies, such as physical, chemical, plasma, and radiation-induced methods, have been employed to create desirable surface properties of PLA biomaterials. So far, three-dimensional porous 
Table 1. PLA based biomaterial in tissue engineering.

\begin{tabular}{|c|c|c|c|c|}
\hline Polymer & Type of implant & Application & Trade name & References \\
\hline $\begin{array}{l}\text { Poly(L-lactic- } \\
\text { coglycolide)/collagen } \\
\text { (PLGA-Collagen) }\end{array}$ & $\begin{array}{l}\text { Fibre matrix } \\
\text { (Fibrous) }\end{array}$ & - Tissue regeneration membrane & Cytoplast resorb & [5] \\
\hline $\begin{array}{l}\text { Poly(L-lactic acid) } \\
\text { (PLLA) }\end{array}$ & Injectable microspheres & $\begin{array}{l}\text { Filling in facial constructive surgery } \\
\text { Embolic material for arteriovenous fis- } \\
\text { tula and malformations, massive haem- } \\
\text { orrhage, and tumours }\end{array}$ & $\begin{array}{l}\text { DEXON, Dacron, BioAncor, } \\
\text { Meniscal Stinger, } \\
\text { The clearfic meniscal dart }\end{array}$ & {$[5,42,43]$} \\
\hline $\begin{array}{l}\text { Poly-L/D-lactide } \\
\text { (PLDLA) }\end{array}$ & Unclear & $\begin{array}{l}\text { - Bioresorbable implant material with im- } \\
\text { proved modulation properties }\end{array}$ & Rosomer & {$[5,42,43]$} \\
\hline $\begin{array}{l}\text { Poly(L-lactic- } \\
\text { co-glycolide) } \\
\text { (PLGA) }\end{array}$ & $\begin{array}{l}\text { Microspheres, } \\
\text { electrospun nanofibres, } \\
\text { meshes, sutures }\end{array}$ & $\begin{array}{l}\text { - Muscle, bone and cartilage and nerves } \\
\text { - Multifilament suture } \\
\text { - Skin graft } \\
\text { - Prostate cancer }\end{array}$ & $\begin{array}{l}\text { Vicryl, } \\
\text { Vicryl rapid \& Cryl Viryl } \\
\text { Mesh LUPRON DEPOT }\end{array}$ & {$[5,42,43]$} \\
\hline $\begin{array}{l}\text { Poly(lactic acid) } \\
\text { (PLA) }\end{array}$ & $\begin{array}{l}\text { Meshes, interference } \\
\text { screws, adhesion barri- } \\
\text { ers, suture anchors, } \\
\text { dural substitutes }\end{array}$ & $\begin{array}{l}\text { - Reconstructive surgery } \\
\text { - Bone, fracture, meniscus, vascular, ar- } \\
\text { ticular and cartilage repairs } \\
\text { - Skin grafting } \\
\text { - Tissue augmentation } \\
\text { - Reconstructive surgeries }\end{array}$ & $\begin{array}{l}\text { Proceed }^{\mathrm{TM}} \text { Surgical } \\
\text { Mesh (Ethicon Inc.), } \\
\text { Artisorb }{ }^{\mathrm{TM}} \text { Bioabsorbable } \\
\text { GTR Barrier (Atrix laborato- } \\
\text { ries, Fort Collins, CO, USA) }\end{array}$ & {$[38]$} \\
\hline $\begin{array}{l}\text { Polyglycolide- } \\
\text { Poly(lactic acid) } \\
\text { (PGA-PLA) }\end{array}$ & Unclear & - Cartilage repair & $\begin{array}{l}\text { (Polyglactin, vicryl) } \\
\text { BioSeed }\end{array}$ & {$[44]$} \\
\hline
\end{tabular}

scaffolds of PLA have been produced for culturing different cell types utilized in cell-based gene therapy for cardiovascular diseases, muscle tissues, bone, and cartilage regeneration $[6,26,32,40,41]$. Over the years, several PLA and PLA stereoisomer-based consumables for tissue engineering applications have been commercialized, and this is summarised in Table 1.

Although PLA has been around for numerous decades, due to high production costs, its use has only been limited to the fabrication of medical devices like sutures [45]. However, Cargill Dow LLC developed a patented, low-cost continuous process to produce lactic acid-based polymers that combines the substantial economic and environmental benefits of both lactide and PLA synthesis in the melt instead of a solution. In turn, this led to the development of a commercially viable commodity polymer derived from renewable sources such as corn and beet sugar, with the potential to substitute conventional fossil fuel derived polymers. The production of PLA consumes less fossil energy compared to petroleum-based polymers and has the potential to reduce air and water pollutant emissions significantly. To date, PLA is the most widely used biodegradable polymer in the field of tissue engineering with a broad application spectrum. This is not only because it is as tough as polymers like polyethylene, polypropylene, and polystyrene, but also because its degradation products are non-toxic to the human body and do not leave any footprints in landfills during decomposition [36, 37, 40, 46, 47]. PLA is generally regarded as safe (GRAS) [37, 48] and thus represents a class of biocompatible polymers that have been successfully developed and safely used as 3-D scaffolds due to their ability to mimic the extracellular matrix. One of the most critical aspects of scaffold fabrication for tissue engineering purposes is the biocompatibility of the material. Biocompatibility refers to the compatibility between the material and the host, including histocompatibility and blood compatibility. Biomedical scientists define biocompatibility as the ability of a scaffold to support cell growth and tissue regeneration intracellularly, without evoking an inflammatory or immunogenic response that may affect the rate of healing and cause rejection of the foreign implant. Features such as non-cytotoxicity, biocompatibility, little to no effect on the phenotypic characteristics of cells, and suitability for three-dimensional spatial structure should be displayed by a good scaffold material $[1,3,26,31,49]$. Besides good structural integrity, it is crucial to be cognizant of the potential toxicity of the polymers' breakdown products, including residues of cross-linking agents of the reactive groups on polymers which have not reacted [36, 40]. Since scaffolds are not intended to be permanent implants, features like biodegradability and bioresobability are crucial in scaffold design and fabrication. 
An ideal implant material will disintegrate over time concurrently with tissue formation because the goal of tissue engineering is to allow body cells to eventually replace the implanted construct. Degradation products of PLA are usually water and carbon dioxide that do not cause any harm; most importantly, they can be totally cleared out of the human body, making PLA the most popular biomedical material in the market $[1,31,34,36,39]$. Equally important when selecting biomaterials in scaffold fabrication is the degradation rate. PLA generally has a slow degradation rate (for polymer mass reaches zero: $3-5$ years in a saline solution at $37^{\circ} \mathrm{C}$ ), which makes it less suitable for short-term application in its purest form. Nonetheless, in applications that require long retention of the strength, such as ligament and tendon reconstruction and stents for vascular and urological surgery, PLA and its derivatives may be preferable biomaterial. To suit many applications in the field of tissue engineering, PLA properties are usually improved through the preparation of lactic acid copolymers and PLAbased composites [3, 32, 38, 44, 50]. Mixing PLA with other natural or synthetic polymers that are hydrophilic and have increased degradation rate provides a practical means to tune its biodegradability to be compatible with the time taken for tissue growth and/or recovery [26, 41, 44].

Apart from biocompatibility and biodegradability, other properties such as thermodynamics and processability also play a pivotal role when selecting biomaterials for tissue engineering implants [51]. Generally, PLA is considered a thermoplastic polymer with high elastic modulus, high tensile strength and low elongation at break $[36,52]$. PLA can revert to a predetermined shape in response to a defined cue, more especially temperature. For instance, PLA changes shape upon heating and cooling: it melts at high temperatures and solidifies into the desired shape merely by cooling. PLA can be subjected to repeated heating and cooling cycles without major changes in the chemical structure, which imparts characteristics of reprocesseabilty and recyclability. As such, PLA has been successfully employed for minimally invasive applications of designed implants that possess shape-memory to potentially reduce the aspect of relatively large objects, allowing them to be implanted through minor operations and then expanding to full geometries. Furthermore, PLA can be easily processed using regular scaffold fabrication techniques, including solvent casting, electrospinning, gas foaming, and others, for the development of a variety of complex $3-D$ porous shapes that are capable of promoting cell adhesion, proliferation, and nutrient transport [53, 54]. Finally, thermal properties of PLA are similar to those of bone tissues [6], which could be an explanation as to why most research is more inclined towards the development of 3-D scaffolds for possible application in the treatment of cardiovascular diseases, muscle tissues, bone and cartilage regeneration.

\section{Poly(lactic acid) containing composites for organ or tissue regeneration}

The range of requirements of prospective tissue engineering biomaterial is broad and specific, and this makes it difficult to achieve these requirements utilizing a single material $[31,55]$. Despite presenting many advantages as a potential material for the fabrication of 3-D scaffolds in tissue engineering, PLA has a few shortcomings. PLA is hydrophobic in nature and lacks the natural recognition site required for cell adhesion, differentiation, and migration [26, $30,38,39,41]$. However, PLA properties can be tuned by blending with other materials to suit the targeted application. Fabrication of composite scaffolds by blending two or more types of biomaterials with selected characteristics may present a suitable and advantageous solution, satisfying all the mechanical and physiological demands of the host tissue $[44,56]$. Different biomaterials can impart different biomechanical forces, which can significantly affect cellular differentiation and migration in a cell type-specific manner [57]. To date, several PLA based micro and/or nanocomposites that include PLA or PLA copolymers as matrices or fillers have displayed great potential in the field of biomedical sciences [34]. Generally, polymer composite materials will exhibit mechanical and physical (physiological) characteristics that make them better suited for a wide range of applications than the individual composite components [46]. Resultantly, several organic and inorganic additives such as gelatin, hydroxyapatite, tricalcium phosphate, and collagen, among others, have been combined with PLA to create implantable composites that are suitable for repairing bone, cartilage, cardiac, and other related defects (Table 2). The incorporation of PLA or its stereoisomers with biologically active materials using a variety of techniques such as electrospinning, solvent casting, superficial $\mathrm{CO}_{2}$, and 3-D bioprinting has resulted in composites 
Table 2. Progress and potential applications of PLA and its composites.

\begin{tabular}{|c|c|c|c|c|}
\hline Composites & Fabrication method & Important properties & Potential application & References \\
\hline $\begin{array}{c}\text { PCL-PLGA- } \beta \text { TCP } \\
\text { (Poly( } \varepsilon \text {-caprolactone) } \\
\text { poly(L-lactide-co-glycol- } \\
\text { ide), } \beta \text {-triphosphate) }\end{array}$ & 3-D bioprinting & $\begin{array}{l}\text { - Osseo-integration } \\
\text { - Ability to form new bone around the } \\
\text { implant }\end{array}$ & Bone reconstruction & {$[4,34]$} \\
\hline $\begin{array}{l}\text { PLLA-Col } \\
\text { (Poly(l-lactic acid), } \\
\text { collagen })\end{array}$ & Electrospinning & $\begin{array}{l}\text { - Remarkable in vitro osteogenesis } \\
\text { - Considerably higher expressions of } \\
\text { osteoblastic genes and increased } \\
\text { quantity and quality of bone minerals } \\
\text { - Even distribution of minerals and for- } \\
\text { mation of large bone aggregates }\end{array}$ & Bone regeneration & {$[6,30]$} \\
\hline $\begin{array}{c}\text { GO-PLGA-Col } \\
\text { (Poly(L-lactic-co-glycol- } \\
\text { ide), collagen and GO.) }\end{array}$ & Electrospinning & $\begin{array}{l}\text { - Help induce spontaneous myogenesis } \\
\text { Increased hydrophobicity of the matri- } \\
\text { ces }\end{array}$ & $\begin{array}{l}\text { Skeletal tissue regener- } \\
\text { ation }\end{array}$ & {$[24,34]$} \\
\hline $\begin{array}{l}\text { PDLLA-Col1 } \\
\text { (Poly(DL-lactide), } \\
\text { collagen 1) }\end{array}$ & Electrospinning & $\begin{array}{l}\text { - Great stability, cell proliferation and } \\
\text { osteogenic differentiation } \\
\text { - Increased hydrophobicity }\end{array}$ & Bone reconstruction & {$[34]$} \\
\hline $\begin{array}{c}\text { PLLA-Hap } \\
\text { (Poly(L-lactic acid), } \\
\text { hydroxyapatite) }\end{array}$ & Unclear & $\begin{array}{l}\text { - Exhibit superior biological perform- } \\
\text { ance }\end{array}$ & Bone defect repair & {$[34,39]$} \\
\hline $\begin{array}{c}\text { PLGA-Hap } \\
\text { (Poly(L-lactic-co-glycol- } \\
\text { ide), hydroxyapatite) }\end{array}$ & Unclear & $\begin{array}{l}\text { - Porosity and increased adhesion ratio } \\
38.8 \pm 3.7 \\
\text { - Increased inflammatory response } \\
\text { - Bioactive surfaces }\end{array}$ & Bone defect repair & {$[34,39]$} \\
\hline $\begin{array}{c}\text { PLA-DBM } \\
\text { (Poly(lactic acid-dem- } \\
\text { ineralized bone matrix) }\end{array}$ & $\begin{array}{l}\text { Superficial } \mathrm{CO}_{2} \\
\text { Technique }\end{array}$ & - Improved mechanical properties & Bone defect repair & [34] \\
\hline $\begin{array}{c}\text { PLGA-TCP } \\
\text { (Poly(L-lactic-co- } \\
\text { glycolide), } \\
\text { tricalcium phosphate) }\end{array}$ & Electrospinning & $\begin{array}{l}\text { - Superior moldability, } \\
\text { - Increased closure behaviour in New } \\
\text { Zealand white rabbits } \\
\text { - Resorption }\end{array}$ & Bone defect repair & [34] \\
\hline $\begin{array}{c}\text { PLLA-Gelatin } \\
\text { (Poly(L-lactic acid), } \\
\text { gelatin) }\end{array}$ & Electrospinning & $\begin{array}{l}\text { - Osteogenic differentiation after seven } \\
\text { days in rats } \\
\text { - Significant formation of new calcified } \\
\text { bone after twelve weeks } \\
\text { - Enhanced cell adhesion and prolifera- } \\
\text { tion }\end{array}$ & Bone defect repair & [34] \\
\hline $\begin{array}{c}\text { PLA-HA } \\
\text { (Poly(lactic acid), hy- } \\
\text { droxyapatite) }\end{array}$ & 3-D printed scaffolds & $\begin{array}{l}\text { - Little inflammation response, } \\
\text { - Relatively larger resorption rate } \\
\text { - Superior osteoinductive activity to en- } \\
\text { hance bone formation }\end{array}$ & Bone defect repair & {$[6,36,39,44,55]$} \\
\hline $\begin{array}{c}\text { PLA-Gelatin } \\
\text { (Poly(lactic acid), gela- } \\
\text { tin) }\end{array}$ & $\begin{array}{l}\text { Electrospinning, } \\
\text { Freeze-drying }\end{array}$ & $\begin{array}{l}\text { - Enhanced cell attachment and prolif- } \\
\text { eration } \\
\text { - Anti-senescence and antiinflammation }\end{array}$ & Cartilage repair & {$[6,30]$} \\
\hline $\begin{array}{c}\text { PLLA-SF } \\
\text { (Poly(l-lactic acid), } \\
\text { Silk Fibroin) }\end{array}$ & Electrospinning & $\begin{array}{l}\text { - Even distribution and adhesion of cells } \\
\text { within the fibrous matrix }\end{array}$ & $\begin{array}{l}\text { Cartilage tissue engi- } \\
\text { neering }\end{array}$ & {$[6,30]$} \\
\hline $\begin{array}{l}\text { Silk Fibroin-PLA } \\
\text { (Sik fibroin, } \\
\text { poly(lactic acid)) }\end{array}$ & Electro-chemical & $\begin{array}{l}\text { - Improved functionality of car- } \\
\text { diomyceds } \\
\text { Enhanced comprehensive modulus } \\
\text { and positive swelling values }\end{array}$ & $\begin{array}{l}\text { Cardiac tissue regener- } \\
\text { ation and nursing appli- } \\
\text { cation }\end{array}$ & {$[30,58]$} \\
\hline
\end{tabular}

with favorable physiological and biological properties when compared to PLA alone [24, 25, 34, 39, 55]. For example, improved mechanical properties have been achieved with the fusion of PLA and Demineralized Bone Matrix (DBM) using the Superficial $\mathrm{CO}_{2}$ technique for repairing bone defects [34], while hydrophobicity has been improved in composites containing PLA and collagen through the electrospinning technique $[24,34]$. Additionally, a superior biological performance, that is, properties that can promote angiogenesis and regulate various cellular activities, including cell migration, proliferation, and extracellular matrix metabolism, has also been realized with PLA incorporated composites. It can, 
therefore, be deduced from the findings summarized in the table below that the incorporation of organic or inorganic bioactive materials into PLA matrices can enhance its mechanical performance and interactions intracellularly.

\section{3-D tissue engineering scaffold fabrication techniques}

In the last four decades, researchers have invented several techniques to mold polymers into complex structures that display the desired characteristics for specific tissue engineering applications [5, 59-61]. These techniques result in reproducible scaffolds for the regeneration of specific tissues or organs. Generally, techniques for tissue engineering rely almost exclusively on the bulk and surface properties of the material. Most techniques involved in scaffold fabrication use the application of heat and/or pressure or dissolving in an organic solvent to form the desired pattern. While each technique may present distinct advantages and disadvantages, a suitable technique must be chosen to address the requirements of specific types of tissues or organs [5]. Essentially, based on the preparation methodology, the properties of the scaffold will vary tremendously. Several fabrication methods, including solvent casting, melt molding, electrospinning, and bioprinting, amongst others, have been used. However, electrospinning and bioprinting are the most preferred and commonly employed in the design and fabrication of 3-D scaffolds. This is because solvent-based techniques tend to leave unwanted salt residues in the scaffold, whereas with techniques like melt molding, the mechanism of cellular uptake is not yet known [29, 33, 35].

Solvent casting is a standard method for the fabrication of tissue engineering scaffolds [62]. In this technique, the polymer is dissolved in a suitable solvent in the presence of uniformly distributed salt particles of a specific size, and then, the resultant solution is cast into a predefined 3-D mold (Figure 2). After casting, the solvent is evaporated, resulting in a salt polymer matrix with uniformly deposited salt particles. Subsequently, the polymer matrix is immersed in water to leach out the salt particles, resulting in a porous structure in which cells can be seeded. The choice of solvent is the key factor as it can influence the polymer surface structure, which includes surface heterogeneity, reorientation of the surface crystal segment, swelling behavior, and deformation rates, which may determine the application of scaffold in

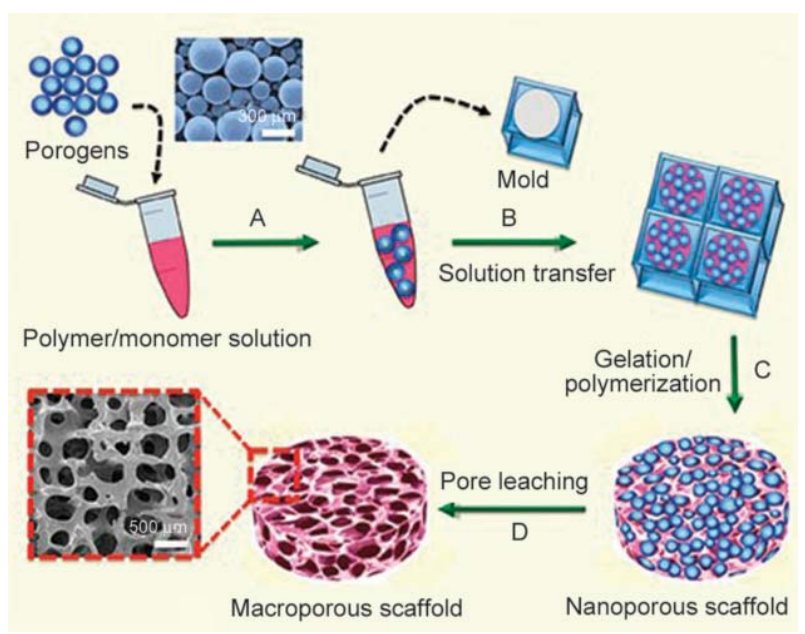

Figure 2. Schematic representation of the solvent casting method [65]. (With permission of PubMed)

tissue engineering. This is one of the simplest scaffold fabrication techniques that does not require any specialized equipment. Its widespread employment is due to shorter preparation times, low running costs, and most importantly, reaction conditions that can be easily varied. The main advantage of using solvent casting is that the pore size and mechanical properties of the scaffold can be easily altered by controlling the size and geometry of the porogen. Technically, this method can be applied to a variety of biodegradable polymers, including PLLA and PGLA containing different lactic acid content by varying the solvent and polymer. Despite its flexibility, the solvent casting method is rarely used to fabricate 3-D scaffolds due to the use of cytotoxic and non-environmental friendly organic solvents $[9,63,64]$.

Freeze-drying, commonly known as lyophilization, is another promising technique for scaffold preparation and has been successfully used in several studies related to PLA and its composites for tissue engineering scaffolds. A polymeric solution is subjected to freezing temperatures, leading to the formation of ice crystals that force the polymer molecules to aggregate into interstitial spaces. The whole process is illustrated in Figure 3. The solvent is then evaporated through sublimation, resulting in polymeric structures with interconnected pores that can be employed in cell seeding. Generally, the resultant scaffold is highly porous but can be further attuned as required by changing the freezing regime, polymer concentration, $\mathrm{pH}$ of the solution as well as the ice crystal size. Moreover, other properties such as solubility and degradation rate of natural polymers can also be modified by cross-linking with UV radiation or chemical 


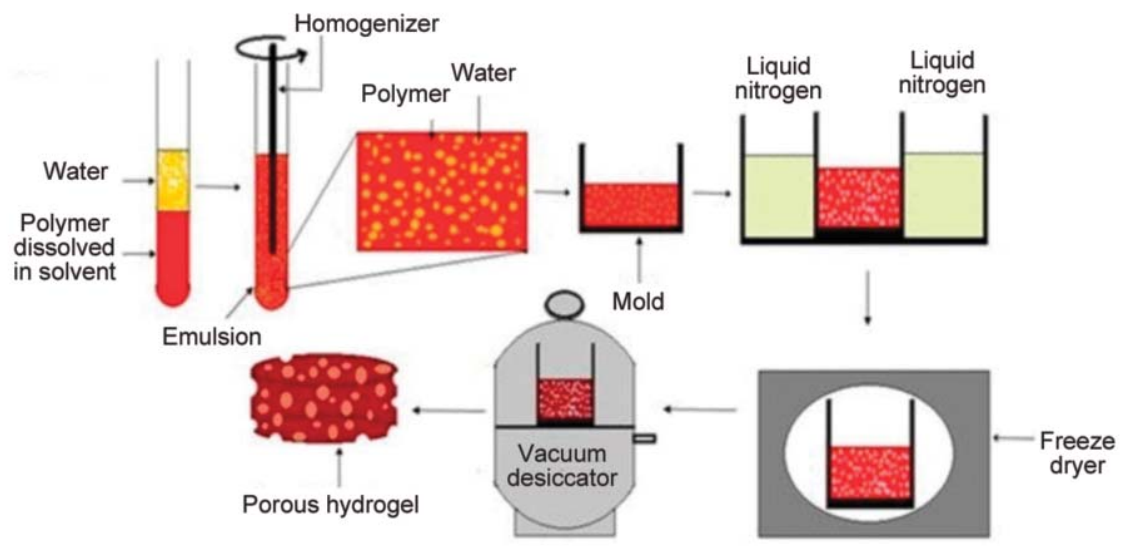

Figure 3. Schematic representation of the freeze-drying method [67]. (With permission of MDPI)

treatment with glutaraldehyde, citric acid, and carbodiimide prior to cell seeding. Although a range of polymers can be freeze-dried and used as implants for cell-matrix interaction studies, it is important to note that due to high energy consumption and long dehydration hours, its application for scaffold fabrication may be limited. Another limiting factor is the potential employment of toxic solvents when mixing the polymer, as they tend to leave undesired residues on the newly formulated scaffold that can potentially harm cells $[9,53,66]$.

Supercritical fluid (SCF) technology is one of the most underused eco-friendly technologies that enables the fabrication of porous 3-D scaffolds for tissue engineering. A summary of the whole SFC process is outlined in Figure 4. The superficial fluid has several advantages over other standard processing techniques, which include the absence of solvents, the ability to include bioactive material without loss of activity, and control over the morphology of the internal porous architecture. A substance becomes a supercritical fluid when it is subjected to an environment or atmosphere where its critical temperature and pressure are exceeded. Liquid and gas phases coexist under supercritical conditions; consequently, SCF exhibits distinctive characteristics of both gaseous and liquid states that are different from those of either liquid or gas under standard conditions. Thus far, carbon dioxide is the most used supercritical fluids because it is fairly inexpensive, non-toxic, readily available, and environmentally friendly. Due to thermodynamics, Super Critical Carbon Dioxide $\left(\mathrm{scCO}_{2}\right)$ has remarkably low critical conditions $\left(T_{\mathrm{c}}=31.1^{\circ} \mathrm{C}, P_{\mathrm{c}}=7.4 \mathrm{MPa}\right)$, making it particularly well suited for processing thermo-sensitive compounds, such as biological compounds. This is an extremely versatile technique that can be applied to

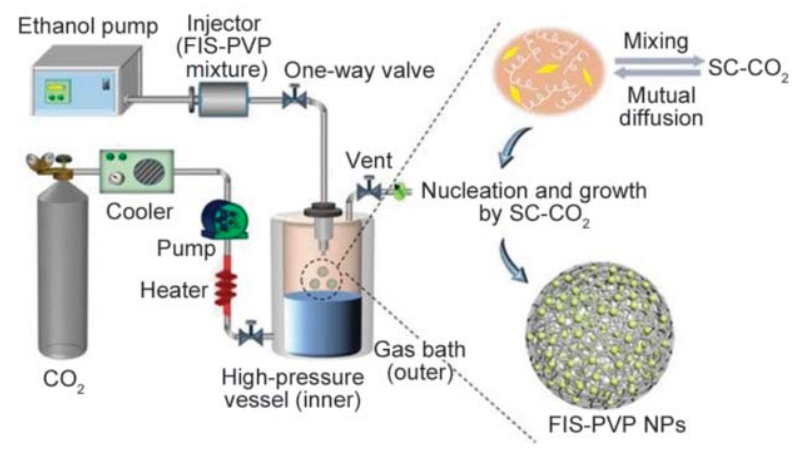

Figure 4. Schematic representation of the Supercritical $\mathrm{CO}_{2}$ device set-up [72]. (With permission of MDPI)

several biopolymers, such as PLA, PLGA, PLLA, as well as some proteins and polysaccharides [68-71]. As a result, highly porous biodegradable PLA scaffolds with a seeding efficiency of close to 95 and up to $40 \%$ viability after just one day of culturing in rats has been reported [9].

Electrospinning is an effective and economical technique for producing continuous fibers with a diameter range from hundreds of nanometres to tens of micrometers from a concentrated solution or melt under a strong electric field, as can be seen in Figure 5 [73]. Polymer characteristics such as porosity, specific surface area, mechanical strength, and morphology can be controlled during the electrospinning process by controlling parameters such as applied voltage and flow rate. Electrospun fibers have unique advantages, such as high aspect ratios, large surfacearea-to volume ratios, open porous structures, and are lightweight. The morphology of electrospun fibers also mimics the native collagen fibrils in the extracellular matrix (ECM). Due to its simplicity and versatility, electrospinning is favored over the other fabrication method for engineering and regenerative medicine purposes. Consequently, this technique has been employed for electrospinning of various polymers 


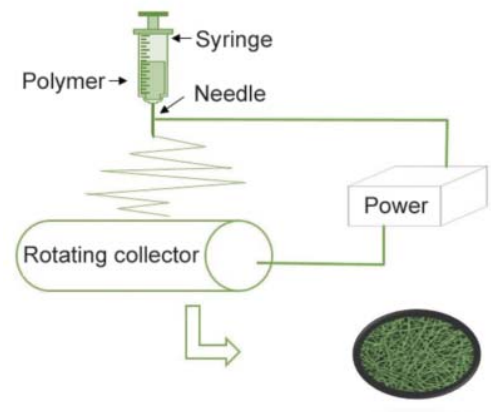

Figure 5. Schematic representation of electrospinning.

such as nylon-6 poly(glycolic acid), poly(lactic acid), poly(lactic-co-glycolic acid), polycaprolactone, polyurethane into nanostructured materials [33, $55,56]$. Nanofibrous poly(L-lactic acid) scaffolds that can imitate the structure of native fibrillar collagen by maintaining macropores that facilitate nutrient and gaseous exchange have also been successfully fabricated using electrospinning [34, 41]. Bioprinting is a novel technique of generating geometrically defined structures that are based on additive manufacturing [4, 74]. Digital information that is usually designed with the aid of computer software like CAD and stryker is converted into tangible objects that can be used to regenerate damaged tissues. This technique can control the physiological appearance and functions of the developed scaffold significantly. The main components in 3-D-bioprinting for constructing 3-D structures are the bio-ink and bio-printer. In contrast to the classical scaffold preparations, bioprinting has the advantage of excellent reproducibility and control over the scaffold structure. Three-dimension bioprinting examples include threedimensional-printed bone scaffolds and orthopedic implants, 3-D-printed molds for personalized tissue-engineered bone regeneration, 3-D direct cell bioprinting for tissue engineering, stereographic 3-D printing for drug-loaded hydrogels, and antimicrobial 3-D bioprinted porous scaffolds. Three-dimensional bioprinting could be integrated with electrospinning, which is a favored technique, and the combination enables the preparation of novel compartmented scaffolds for tissue engineering and regenerative medicine [4, 22, 33, 35, 75]. Regardless of its adoption as a biomaterial for clinical application and engineering tissues in vitro, PLA and its derivatives have not been adopted as a bioink for use with 3-D printers [76]. They are currently being used as reinforcing materials for bioinks [37, 64].

\section{Conclusions}

The review was based on the use of PLA and its composites as functional materials for 3-D scaffolding. A lot of research has been conducted globally on PLA and its composites as a prospective biomaterial for scaffolds that can mimic the native tissue. PLA presents many integral attributes of any good biomaterial, that is, eco-friendliness, biocompatibility, biodegradability, and processability. However, PLA alone cannot meet all the demands of 3-D geometries for organ replacement. Thus, PLA must be used in conjunction with other materials, organic or inorganic, to satisfy the requirements of fabrication and design. Composites of PLA and/or its stereoisomers with other materials through different fabrication techniques have illustrated enhanced mechanical performance and intracellular interactions in previous studies. So far, they have demonstrated great potential in rectifying skin, bone, and cartilage defects, amongst others. Although there are many PLA derived commercial products for medical applications, almost all the researchers agree that there is still a lot of work to be done before organs generated from these biomaterials can fully compete with donor and prosthetic organs for large organ transplantation.

\section{Future recommendations}

It is without a doubt that research has made tremendous progress on the development of PLA and composites as potential material for 3-D scaffolding, especially in the areas of bone reconstruction. However, great challenges and opportunities remain in terms of exploring the characteristics of PLA-based materials and expanding their domains of applications. Thus, more work remains in modifications of PLA properties, leaving more room for further improvements of composites, particularly where biodegradability is concerned as it continues to limit the scope of PLA application. Furthermore, researchers can consider developing a single, all in one unit or machine which is a combination of the best of the fabrication techniques available to allow for customization of PLA composites on demand and as desired in biomedical applications guided by patient conditions. 


\section{Acknowledgements}

The National Research Foundation (NRF) for postgraduate scholarship and Central University of Technology (CUT) postgraduate student funds are acknowledged by S.T. Sikhosana for financial support of the project. The National Research Foundation for Black Academics Advancement Programme (BAAP) and the Scholarship of Teaching and Learning (SOTL) are acknowledged by T.P. Gumede for financial support.

\section{References}

[1] O'Brien F. J.: Biomaterials \& scaffolds for tissue engineering. Materials Today, 14, 88-95 (2011). https://doi.org/10.1016/S1369-7021(11)70058-X

[2] Zhao P., Gu H., Mi H., Rao C., Fu J., Turing L-S.: Fabrication of scaffolds in tissue engineering: A review. Frontier Mechanical Engineering, 13, 107-119 (2018). https://doi.org/10.1007/s11465-018-0496-8

[3] Murphy C. M., O’Brien F. J., Little D. G., Schindeler A.: Cell-scaffold interactions in the bone tissue engineering TRIAD. European Cells and Materials, 26, 120-132 (2013). https://doi.org/10.22203/eCM.v026a09

[4] Erten E., Arslan Y. E.: The great harmony in translational medicine: Biomaterials and stem cells. Advanced in Experimental Medicine and Biology, 4, 21-39 (2018). https://doi.org/10.1007/5584_2018_231

[5] Dhandayuthapani B., Yoshida Y., Maekawa T., Kumar D. S.: Polymeric scaffolds in tissue engineering application: A review. International Journal of Polymer Science, 2011, 290602/1-290602/19 (2011).

https://doi.org/10.1155/2011/290602

[6] Fattahi F., Khoddami A., Avinc O.: Poly (lactic acid) (PLA) nanofibers for bone tissue engineering. Journal of Textile and Polymers, 7, 1-64 (2019).

[7] Salminger S., Roche A. D., Sturma A., Mayer J. A., Aszmann O. C.: Hand transplantation versus hand prosthetics: Pros and cons. Current Surgery Reports, 4, 8/18/7 (2016).

https://doi.org/10.1007/s40137-016-0128-3

[8] Rebelo R., Fernandes M., Fangueiro R.: Biopolymers in medical implants: A brief review. Procedia Engineering, 200, 236-243 (2017).

https://doi.org/10.1016/j.proeng.2017.07.034

[9] Bajaj P., Schweller R. M., Khademhosseini A., West J. L., Bashir R.: 3D biofabrication strategies for tissue engineering and regenerative medicine. Annual Review of Biomedical Engineering, 16, 247-276 (2014). https://doi.org/10.1146/annurev-bioeng-071813-105155
[10] Giwa S., Lewis J. K., Alvarez L., Langer R., Roth A. E., Church G. M., Markmann J. F., Sachs D. H., Chandraker A., Wertheim J. A., Rothblatt M., Boyden E. S., Eidbo E., Lee W. P. A., Pomahac B., Brandacher G., Weinstock D. M., Elliott G., Nelson D., Acker J. P., Uygun K., Schmalz B., Weegman B. P., Tocchio A., Fahy G. M., Storey K. B., Rubinsky B. Bischof J., Elliott J. A. W., Woodruff T. K., Morris G. J., Demirci U., Brockbank K. G. M., Woods E. J., Ben R. N., Baust J. G., Gao D., Fuller B., Rabin Y., Kravitz D. C., Taylor M. J., Toner M.: The promise of organ and tissue preservation to transform medicine. Nature Biotechnology, 35, 530542 (2017).

https://doi.org/10.1038/nbt.3889

[11] Kurniawan N. A.: The ins and outs of engineering functional tissues and organs: Evaluating the in-vitro and insitu processes. Current Opinion in Organ Transplantation, 24, 590-597 (2019).

https://doi.org/10.1097/MOT.0000000000000690

[12] Abbas S. H., Friend J. M.: Principles and current status of abdominal organ preservation for transplantation. Surgery in Practice and Science, 3, 100020/1-100020/7 (2020). https://doi.org/10.1016/j.sipas.2020.100020

[13] Yang L.: Safety of nanotechnology-enhanced orthopedic materials. in 'Nanotechnology-enhanced orthopedic materials' (ed.: Yang L.) Woodhead, Worcester, 1, 181195 (2015).

https://doi.org/10.1016/b978-0-85709-844-3.00009-4

[14] Dixit S., Baganizi D. R., Sahu R., Dosunmu E., Chaudhari A., Vig K., Pillai S. R., Singh S. R., Dennis V. A.: Immunological challenges associated with artificial skin grafts: Available solutions and stem cells in future design of synthetic skin. Journal of Biological Engineering, 11, 49/1-49/23 (2017).

https://doi.org/10.1186/s13036-017-0089-9

[15] Dzobo K., Thomford N. E., Senthebane D. A., Shipanga H., Rowe A., Dandara C., Pillay M., Motaung K. S. C. M.: Advances in regenerative medicine and tissue engineering: Innovation and transformation of medicine. Stem Cells International, 2018, 2495848/1-2495848/24 (2018).

https://doi.org/10.1155/2018/2495848

[16] Ochando J., Charron D., Baptista P. M., Uygun B. E.: Immune responses to bioengineered organs. Current Opinion in Organ Transplantation, 22, 79-85 (2016). https://doi.org/10.1097/MOT.0000000000000378

[17] Hunsberger J., Neubert J., Wertheim J. A., Allickson J., Atala A.: Bioengineering priorities on a path to ending organ shortage. Current Stem Cell Reports, 2, 118-127 (2016).

https://doi.org/10.1007/s40778-016-0038-4 
[18] Rouchi A. H., Mahdavi-Mazdeh M.: Regenerative medicine in organ and tissue transplantation: Shortly and practically achievable? International Journal of Organ Transplantation Medicine, 6, 93-98 (2015).

[19] Jahanbani Y., Davaran S., Ghahremani-Nasab M., Aghebati-Maleki L., Yousefi M.: Scaffold-based tissue engineering approaches in treating infertility. Life Sciences, 240, 117066/1-117066/28 (2020). https://doi.org/10.1016/j.lfs.2019.117066

[20] Dorin R. P., Koh C. J.: Fetal tissues. in 'Principles of regenerative medicine' (eds.: Atala A., Lanza R., Thomson A. A., Nerem R.) Academic Press, California, Vol 1, 819-832 (2011).

https://doi.org/10.1016/B978-0-12-381422-7.10045-8

[21] MacNeil S.: Biomaterials for tissue engineering of skin. Materials Today, 11, 26-35 (2008).

https://doi.org/10.1016/S1369-7021(08)70087-7

[22] Berthiaume F., Maguire T. J., Yarmush M. L.: Tissue engineering and regenerative medicine: History, progress, and challenges. Annual Review of Chemical and Biomolecular Engineering, 2, 403-430 (2011). https://doi.org/10.1146/annurev-chembioeng-061010-114257

[23] Chaudhari A. A., Vig K., Baganizi D. R., Sahu R., Dixit S., Dennis V., Singh S. R., Pillai S. R.: Future prospects for scaffolding methods and biomaterials in skin tissue engineering: A review. International Journal of Molecular Sciences, 17, 1974/1-1974/31 (2016). https://doi.org/10.3390/ijms17121974

[24] Cao H., Chen M-M., Liu Y., Liu Y-Y., Huang Y-Q., Wang J-H., Chen J-D., Zhang Q-Q.: Fish collagen-based scaffold containing PLGA microspheres for controlled growth factor delivery in skin tissue engineering. Colloids and Surfaces B: Biointerfaces, 136, 1098-1106 (2015). https://doi.org/10.1016/j.colsurfb.2015.10.022

[25] Revati R., Majid M. S. A., Ridzuan M. J. M., Normahira M., Nasir N. F. M., Cheng E. M.: Biodegradation of PLA-pennisetum purpureum based biocomposite scaffold. IOP Conference Series: Journal of Physics, 908, 012029/1-012029/10 (2017).

https://doi.org/10.1088/1742-6596/908/1/012029

[26] Santoro M., Shah S. R., Walker J. L., Mikos A. G.: Poly (lactic acid) nanofibrous scaffolds for tissue engineering. Advanced Drug Delivery Review, 107, 206-212 (2016).

https://doi.org/10.1016/j.addr.2016.04.019

[27] Lee E. J., Kasper F. K., Mikos A. G.: Biomaterials for tissue engineering. Annals of Biomedical Engineering, 42, 323-337 (2013). https://doi.org/10.1007/s10439-013-0859-6

[28] Keane T. J., Badylak S. F.: Biomaterials for tissue engineering applications. Seminars in Pediatric Surgery, 23, 112-118 (2014) https://doi.org/10.1053/j.sempedsurg.2014.06.010

[29] Revati R., Majid M. S. A., Normahira M.: Biodegradable poly(lactic acid) scaffold for tissue engineering: A brief review. Journal of Polymer Science and Technology, 1, 16-24 (2015).
[30] Fattahi F. S.: Poly (lactic acid) nano-structures for cartilage regeneration and joint repair: Strategies and ideas. Recent Trends Nanoscience Technology, 1, 1-19 (2020).

[31] Lopes M. S., Jardini A. L., Filho R. M.: Poly (lactic acid) production for tissue engineering applications. Procedia Engineering, 42, 1402-1413 (2012). https://doi.org/10.1016/j.proeng.2012.07.534

[32] Narayanan G., Vernekar V. N., Kuyinu E. L., Laurencin C. T.: Poly(lactic acid)-based biomaterials for orthopaedic regenerative engineering. Advanced Drug Delivery Reviews, 107, 247-276 (2016). https://doi.org/10.1016/j.addr.2016.04.015

[33] Eltom A., Zhong G., Muhammad A.: Scaffold techniques and designs in tissue engineering functions and purposes: A review. Advances in Materials Science and Engineering, 2019, 3429527/1-3429527/13 (2019). https://doi.org/10.1155/2019/3429527

[34] Sha L., Chen Z., Chen Z., Zhang A., Yang Z.: Polylactic acid based nanocomposites: Promising safe and biodegradable materials in biomedical field. International Journal of Polymer Science, 2016, 6869154/16869154/11 (2016).

https://doi.org/10.1155/2016/6869154

[35] Singh D., Babbar A., Jain V., Gupta D., Saxena S., Dwibedi V.: Synthesis, characterization, and bioactivity investigation of biomimetic biodegradable PLA scaffold fabricated by fused filament fabrication process. Journal of the Brazilian Society of Mechanical Sciences and Engineering, 41, 121/1-121/13 (2019).

https://doi.org/10.1007/s40430-019-1625-y

[36] Pawar R. P., Tekale S. U., Shisodia S. U., Totre J. T., Domb A. J.: Biomedical applications of poly(lactic acid). Recent Patents on Regenerative Medicine, 4, 40-51 (2014). https://doi.org/10.2174/2210296504666140402235024

[37] Fairag R., Rosenzweig D. H., Ramirez-Garcialuna J. L., Weber M. H., Haglund L.: Three-dimensional printed polylactic acid scaffolds promote bone-like matrix deposition in vitro. ACS Applied Materials and Interfaces, 11, 15306-15315 (2019). https://doi.org/10.1021/acsami.9b02502

[38] Manavitehrani I., Fathi A., Badr H., Daly S., Shirazi A. N., Dehghani F.: Biomedical applications of biodegradable polyesters. Polymers, 8, 20/1-20/32 (2016). https://doi.org/10.3390/polym8010020

[39] Davachi S. M., Kaffashi B.: Polylactic acid in medicine. Polymer-Plastics Technology and Engineering, 54, 944-967 (2015). https://doi.org/10.1080/03602559.2014.979507

[40] Hamad K., Kaseem M., Yang H. W., Deri F., Ko Y. G.: Properties and medical applications of polylactic acid: A review. Express Polymer Letters, 9, 435-455 (2015). https://doi.org/10.3144/expresspolymlett.2015.42 
[41] Valencia C. H.: Hydrolytic degradation and in vivo resorption of poly-L-lactic acid-chitosan biomedical devices in the parietal bones of Wistar rats. Journal of International Medical Research, 47, 1705-1716 (2019). https://doi.org/10.1177/0300060519828935

[42] Haider A., Haider S., Kummara M. R., Kamal T., Alghyamah A-A. A., Iftikhar F. J., Bano B., Khan N., Afridi M. A., Han S. S., Alrahlah A., Khan R.: Advances in the scaffolds fabrication techniques using biocompatible polymers and their biomedical application: A technical and statistical review. Journal of Saudi Chemical Society, 24, 186-215 (2020).

https://doi.org/10.1016/j.jscs.2020.01.002

[43] Alsaheb A. A., Aladdin A., Othman N. Z., Malek R. A., Leng O. M., Aziz R., El Enshasy H. A.: Recent applications of polylactic acid in pharmaceutical and medical industries. Journal of Chemical and Pharmaceutical Research, 7, 51-63 (2015).

[44] Singhvi M. S., Zinjarde S. S., Gokhale D. V.: Polylactic acid: Synthesis and biomedical applications. Journal of Applied Microbiology, 127, 1612-1626 (2019). https://doi.org/10.1111/jam.14290

[45] Rocca-Smith J. R., Lagorce-Tachon A., Iaconelli C., Bellat J. P., Marcuzzo E., Sensidoni A., Piasente F., Debeaufort F., Karbowiak T.: How high pressure $\mathrm{CO}_{2}$ impacts PLA film properties. Express Polymer Letters, 11, 320-333 (2017). https://doi.org/10.3144/expresspolymlett.2017.31

[46] Petinakis E., Yu L., Simon G., Dean K.: Natural fibre bio-composites incorporating poly(lactic acid). in 'Fiber reinforced polymers - The technology applied for concrete repair' (ed.: Masuelli M.) IntechOpen, Melbourne, 41-58 (2013). https://doi.org/10.5772/52253

[47] de Oliveira Sousa Neto V., do Nascimento R. F.: Recent progress in biocomposite of biodegradable polymer. in 'Handbook of composites from renewable materials' (eds.: Thakur V. K., Thakur M. K., Kessler M. R.) Scrivener Publishing, Beverly, 61-94 (2017). https://doi.org/10.1002/9781119441632.ch86

[48] Kim I., Viswanathan K., Kasi G., Sadeghi K. Thanakkasaranee S., Seo J.: Poly(lactic acid)/ZnO bionanocomposite films with positively charged $\mathrm{ZnO}$ as potential antimicrobial food packaging materials. Polymers, 11, 1427/1-1427/17 (2019).

https://doi.org/10.3390/polym11091427

[49] Wang Z-R., Qiu Z-Y., Cui Y.: Biomimetic mineralized collagen biocompatibility. in 'Mineralized collagen bone graft substitutes' (eds.: Wang Z., Cui Y., Qiu Z.) Woodhead, Winston-Salem, 61-98 (2019). https://doi.org/10.1016/B978-0-08-102717-2.00003-5

[50] Konta A. A., García-Piña M., Serrano D. R.: Personalised 3D printed medicines: Which techniques and polymers are more successful? Bioengineering, 4, 79/179/16 (2017).

https://doi.org/10.3390/bioengineering4040079
[51] Wang K., Strandman S., Zhu X. X.: A mini review: Shape memory polymers for biomedical applications. Frontiers of Chemical Science and Engineering, 11, 143-153 (2017). https://doi.org/10.1007/s11705-017-1632-4

[52] Xu J., Song J.: Polylactic acid (PLA)-based shapememory materials for biomedical applications. in 'Shape memory polymers for biomedical applications' (ed.: Yahia L.) Woodhead, Worcester, 196-216 (2015). https://doi.org/10.1016/B978-0-85709-698-2.00010-6

[53] Deb P. K., Kokaz S. F., Abed S. N., Paradkar A., Tekade R. K.: Pharmaceutical and biomedical applications of polymers. in 'Basic fundamentals of drug delivery' (eds.: Tekade R. K.), Academic Press, California, 203-267 (2019). https://doi.org/10.1016/B978-0-12-817909-3.00006-6

[54] Kohane D. S., Langer R.: Polymeric biomaterials in tissue engineering. Pediatric Research, 63, 487-491 (2008). https://doi.org/10.1203/01.pdr.0000305937.26105.e7

[55] Rogina A.: Electrospinning process: Versatile preparation method for biodegradable and natural polymers and biocomposite systems applied in tissue engineering and drug delivery. Applied Surface Science, 296, 221230 (2014)

https://doi.org/10.1016/j.apsusc.2014.01.098

[56] Gunn J., Zhang M.: Polyblend nanofibers for biomedical applications: Perspectives and challenges. Trends in Biotechnology, 28, 189-197 (2010). https://doi.org/10.1016/j.tibtech.2009.12.006

[57] Guarino V., Causa F., Taddei P., di Foggia M., Ciapetti G., Martini D., Fagnano C., Baldini N., Ambrosio L.: Polylactic acid fibre-reinforced polycaprolactone scaffolds for bone tissue engineering. Biomaterials, 29, 3662-3670 (2008).

https://doi.org/10.1016/j.biomaterials.2008.05.024

[58] Yan C., Ren Y., Sun X., Jin L., Liu X., Chen H., Wang K., Yu M., Zhao Y.: Photoluminescent functionalized carbon quantum dots loaded electroactive silk fibroin/ PLA nanofibrous bioactive scaffolds for cardiac tissue engineering. Journal of Photochemistry and Photobiology B: Biology, 202, 111680/1-111680/35 (2020). https://doi.org/10.1016/j.jphotobiol.2019.111680

[59] Burke J. F., Yannas O. V., Quinby W. C., Bondoc C. C. M. D., Jung W. K. M. D.: Successful use of a physiologically acceptable artificial skin in the treatment of extensive burn injury. Annals of Surgery, 194, 413-427 (1981). https://doi.org/10.1097/00000658-198110000-00005

[60] Lu L., Mikos A. G.: The importance of new processing techniques in tissue engineering. MRS Bulletin, 21, 2832 (1996)

https://doi.org/10.1557/S088376940003181

[61] Hutmacher D. W.: Scaffold design and fabrication technologies for engineering tissues - State of the art and future perspectives. Journal of Biomaterials Science, 12, 107-124 (2001) https://doi.org/10.1163/156856201744489 
[62] Sola A., Bertacchini J., D’Avella D., Anselmi L., Maraldi T., Marmiroli S., Messori M.: Development of solventcasting particulate leaching (SCPL) polymer scaffolds as improved three-dimensional supports to mimic the bone marrow niche. Material Science and Engineering: C, 1, 153-165 (2018). https://doi.org/10.1016/j.msec.2018.10.086

[63] Wahid F., Khan T., Hussain Z., Ullah H.: Nanocomposite scaffolds for tissue engineering; Properties, preparation and applications. in 'Applications of nanocomposite materials in drug delivery' (eds.: Inamuddin A., Asiri A. A, Mohammed A.) Woodhead Publishing, Worcester, 701-735 (2018). https://doi.org/10.1016/B978-0-12-813741-3.00031-5

[64] Huang R., Zhu X., Tu H., Wan A.: The crystallization behaviour of porous poly(lactic acid) prepared by modified solvent casting/particulate leaching technique for potential use of tissue engineering scaffold. Materials Letters, 136, 126-129 (2014). https://doi.org/10.1016/j.matlet.2014.08.044

[65] Bencherif S. A., Braschler T. M., Renaud P.: Advances in the design of macroporous polymer scaffolds for potential applications in dentistry. Journal of Periodontal and Implant Science, 43, 251-261 (2013). https://doi.org/10.5051/jpis.2013.43.6.251

[66] Brougham C. M., Levingstone T. J., Shen N., Cooney G. M., Jockenhoevel S., Flanagan T. C., O’Brien F. J.: Freeze-drying as a novel biofabrication method for achieving a controlled microarchitecture within large, complex natural biomaterial scaffolds. Advanced Healthcare Materials, 6, 1700598/1-1700598/7 (2017). https://doi.org/10.1002/adhm.201700598

[67] Sampath U. G. T. M., Ching Y., Chuah C., Sabariah J. J., Lin P-C.: Fabrication of porous materials from natural/synthetic biopolymers and their composites. Materials, 9, 991/1-991/32 (2016). https://doi.org/10.3390/ma9120991

[68] Tsai W-C., Wang Y.: Progress of supercritical fluid technology in polymerization and its applications in biomedical engineering. Progress in Polymer Science, 98, 101161/1-101161/18 (2019). https://doi.org/10.1016/j.progpolymsci.2019.101161
[69] Salerno A., Pascual C. D.: Bio-based polymers, supercritical fluids and tissue engineering. Process Biochemistry, 50, 826-838 (2015).

https://doi.org/10.1016/j.procbio.2015.02.009

[70] Montes A., Pereyra C., de la Ossa E. M.: Foaming + impregnation one-step process using supercritical $\mathrm{CO}_{2}$. in 'Advanced supercritical fluids technologies' (ed.: Pioro I.) IntechOpen, Rijeka, 203-267 (2020). https://doi.org/10.5772/intechopen.91304

[71] Duarte A. R. C., Mano J. F., Reis R. L.: Supercritical fluids in biomedical and tissue engineering applications: A review. International Materials Reviews, 54, 214-222 (2009). https://doi.org/10.1179/174328009X411181

[72] Chen L-F., Xu P-Y., Fu C-P., Kankala R. K., Chen A-Z., Wang S-B.: Fabrication of supercritical antisolvent (SAS) process-assisted fisetin-encapsulated poly (vinyl pyrrolidone) (PVP) nanocomposites for improved anticancer therapy. Nanomaterials, 10, 322/1-322/14 (2020). https://doi.org/10.3390/nano10020322

[73] Mi H-Y., Jing X., Napiwocki B. N., Li Z-T., Turng L-S., Huang H-X.: Fabrication of fibrous silica sponges by self-assembly electrospinning and their application in tissue engineering for three-dimensional tissue regeneration. Chemical Engineering Journal, 331, 652-662 (2017). https://doi.org/10.1016/j.cej.2017.09.020

[74] Goel A., Meher M. K., Gulati K., Poluri K. M.: Fabrication of biopolymer-based organs and tissues using $3 \mathrm{D}$ bioprinting. in ' $3 \mathrm{D}$ printing technology in nanomedicine' (eds.: Ahmad N., Gopinath P., Dutta R) Elsevier, St Luis, 43-62 (2019). https://doi.org/10.1016/B978-0-12-815890-6.00003-7

[75] Gopinathan J., Noh I.: Recent trends in bioinks for 3D printing. Biomaterials Research, 22, 11/1-11/15 (2018). https://doi.org/10.1186/s40824-018-0122-1

[76] Willerth S. M., Sakiyama-Elbert S. E.: Combining stem cells and biomaterial scaffolds for constructing tissues and cell delivery. Stem Journal, 1, 1-25 (2019). https://doi.org/10.3233/STJ-180001 